\title{
A RESEARCH PAPER QUESTIONNAIRE BASED ON LIBRARY RESEARCH
}

\author{
Haru Deliana Dewi \\ English Study Program, Faculty of Humanities, Universitas Indonesia, harudeguchi@yahoo.com
}

DOI: 10.17510/paradigma.v6i1.83.

\begin{abstract}
ABSTRAK
Makalah ini membahas aturan-aturan dan tantangan-tantangan dalam membuat suatu kuesioner dalam mengumpulkan data untuk makalah penelitian. Ada beberapa pertimbangan dan isu-isu etis yang perlu kita perhatikan ketika menyusun suatu kuesioner. Selanjutnya, tahapan dalam membuat dan memilih pertanyaan akan dibahas untuk membuat survei kita efektif. Makalah ini memasukkan, membandingkan, dan mengkontraskan pendapat-pendapat para ahli yang menulis tentang pembuatan pertanyaan untuk suatu kuesioner. Selain itu, makalah ini juga dilengkapi dengan contohcontoh kuesioner yang baik dan benar yang terdapat pada lampiran.
\end{abstract}

\section{KATA KUNCI}

Kuesioner; Makalah Penelitian; Survei; Pertanyaan.

\section{Introduction}

In making a research paper, the primary data are as important as the secondary data. The primary data are the data obtained via surveys, questionnaires, or interview; in other words, those are the data obtained directly from the source persons. The secondary data, however, are obtained from journal articles, books, newspapers, and other published/written materials. Thus, the secondary data are the data obtained indirectly. When we would like to conduct research in a country where the printed or official source is sparse or non-existent, doing oral history and conducting survey are several ways we may choose to collect data from people. In doing oral history, we have to record the dialogue and make the transcription, which will 
be a great deal of work, while conducting survey has slightly less complexity to obtain the results from questionnaires since they are already in a written form.

However, developing a questionnaire is by no means easy. There are a lot of steps to do and some considerations to think about before we make the questions. Moreover, we need to understand some ethical issues in asking people questions. What makes it even more complicated is to design a questionnaire to ask about the past, about history, since human memories are limited ${ }^{1}$. Therefore, although there are plenty of good techniques in several books to make questions for a questionnaire, preparing it to collect data for a research paper is very challenging.

\section{Considerations before Making the Questionnaire and Ethical Issues}

As "surveys are used to collect information from or about people to describe, compare, or explain their knowledge, feelings, values, and behavior" (Fink 2006, 1), we have to consider ways to motivate people to respond to the questionnaire we make so that we can collect data successfully. First, we have to provide information about our research to the potential respondents (Dillman et al. 2009, 23). By sending information to the potential respondent, it can encourage survey participation (Groves et al., 1992). According to Peterson $(2000,102-105)$, providing information is part of the crucial components of a questionnaire. In addition, Gillham also believes that if respondents are clear about what we are trying to find out and why, they are much more likely to respond appropriately and helpfully $(2000,38)$. The information should be written in the introduction section (Peterson 2000, 102) or in the covering letter of explanation (Gillham 2000, 37), and it is often separate from the questionnaire.

Second, besides providing information about our research, both Dillman et al. (2009) and Peterson (2000) agree that the introduction section should contain a request for a help or a favor. Most people will feel more encouraged to respond to a questionnaire when they are asked for a favor (Groves et al., 1992) since it will give them a sense of reward from knowing they have helped others (Blau 1964; Homans 1961). Those two components are the similarities found in Dillman et al. (2009) and Peterson (2000). Gillham does not mention about this explicitly, but he shows it in the example $(2000,38)$. Based on the suggestions above, before sending the questionnaire to the potential respondents, a letter would be delivered via email to provide information about our research and to request for a favor with the hope that they will be willing

1. This is proven by an article entitled The Limitations of Human Memory: Implications for the Design of Retrospective Surveys written by Baddeley (2004, 29-45). 
and feel encouraged to respond to our questionnaire. The example of an introduction section can be seen in Appendix 1.

For other ways of motivating people to respond to our questionnaires, Dillman et al. and Peterson show some differences, while in Gillham's book there is no explicit and direct explanation about how to motivate respondents, although from the example provided we can see some ideas of how to do it. Dillman et al. state that to motivate respondents, we should show positive regard, say thank you, support group values (support for shared values), give tangible rewards, make the questionnaire interesting, provide social validation (knowing that other people similar to themselves have completed the survey), and inform people that opportunities to respond are limited $(2009,24-25)$. All those ways can strongly influence people to participate in our survey. We may choose to do all of the ways or just some of them depending on our ability and condition. For example, to give tangible rewards, such as money or some small items like a pencil or a pen, can cost a lot, so if we cannot afford it, we should not force ourselves to do it.

Peterson and Gillham have more similar ideas to motivate respondents. Both suggest to personalize the letter or the introduction section through the salutation, so instead of writing "Dear Sir or Madam" or "To Whom It May Concern', we should write "Dear Mr. Smith" for example. Besides the salutation, the personal signature of a researcher is important too. Although there is no detailed explanation of the reason for doing this way by both Peterson and Gillham, the attempt of personalization, I believe, could draw the attention of the potential respondents and make them feel special. Another way is by giving the respondents an assurance of confidentiality or anonymity by writing, for example, "Your answers will, of course, be strictly confidential" (Peterson 2000, 105). However, 'confidential' does not mean 'anonymous' according to Gillham $(2000,39)$. Therefore, we should also write "This questionnaire is anonymous." Although no explanation on the reason for doing this way is given by Peterson and Gillham, I believe giving the assurance of confidentiality and/or anonymity will encourage reluctant respondents to fill in the questionnaire without any fear or embarassment.

Several of the ways to motivate people mentioned above are, surprisingly, written as ethical responsibilities in other books. Fowler states that providing information about our research is a part of our responsibilities to the respondents since they have the rights to know $(2002,151-152)$. Fink also states that the information about the research, such as the title of the research or survey, the purpose, the procedures, the potential risks and benefits, whether there will be payment or not, the withdrawal procedure, and the identification of surveyors, should be written in an informed consent form $(2006,41)$. Moreover, giving an 
assurance of confidentiality and anonymity is part of ethical responsibilies too and should be written in the consent form as well. The following is the statement from Fink about confidentiality and anonymity.

The use of surveys and concern for ethical issues are completely interwoven. Survey are conducted because of the need to know; ethical considerations protect the individual's right to privacy or even anonymity (Fink 2006: 41).

It shows that there is a clash or conflict of interest between the purpose of survey and the purpose of ethical considerations. The ways to motivate respondents to respond to our questionnaire are also ways to pay attention to ethical considerations, so they are not merely optional suggestions to do. Those are steps to be done before the questionnaires are sent.

\section{Making and Selecting the Questions}

I believe the first thing to consider before making the questions is to find out the format of the questions, and then we should learn the order of the questions arranged in the questionnaire which will give maximum results. For the format of the questions, there are two basic types: open-ended questions and closed-ended questions. ${ }^{2}$ The explanation of those two kinds of questions is referred to Peterson. He states that in open-ended questions the participants are free to provide any answer, while in closed-ended questions answers are provided for the participants to choose $(2000,29)$. Fowler describes that the advantages of open-ended questions are they permit us to obtain unanticipated answers and they are closely the real views of the respondents, while the advantages of close-ended questions are the answers can be more reliable and more analytically useful $(2002,91)$.

Which one is better for our questionnaire? Fink (2006) gives examples of surveys with open-ended questions only and with closed-ended questions only depending on the purpose of the survey. Dillman et al. $(2009,72-77)$ elaborate the strenghts and limitations of each question type that researchers should be aware of and explain when each type should be used. They even mention a hybrid of open and close-ended formats (a partially closed question format) as an alternative but not necessarily as the best format to use. On the other hand, according to Peterson, "it is more meaningful to consider the two question types as complements rather than substitutes for each other" $(2000,30)$. He seems to suggest that the combination of two question types will be better than just choosing either type because it will cover variety of answers. For the sample of

2. This seems to be general knowledge since these two types are mentioned in every book about questionnaire questions. 
the questionnaire provided in the appendix, both formats are incorporated to obtain more data and to make the survey interesting. Having only one type of questions will be dull for the respondents (Fink 2006, 33).

For the order of the questions, Fink suggests we start from the most familiar to the least familiar questions for the respondents, and questions of recall or retrospective questions should be organized according to their natural sequence $(2006,33)$. Gillham gives more specific explanation about the order of the questions. He writes that factual questions usually come first and in chronological order, while questions about opinions, beliefs, judgements, and behaviour should come afterwards since they are more challenging to answer $(2000,26-27)$. If we write difficult questions first, it will discourage the participants from the beginning. I agree with both authors, so the questions in the sample of the questionnaire are arranged from facts first (the most familiar ones for the repondents) and then continued to questions about opinions (the least familiar). The example of the questions can be seen in Appendix 2.

The next thing we should pay attention to is the wording of the questions to increase the reliability of the answers. The questions could be the retrospective ones, which are questions to recall past circumstances, conditions, or relationships (Menner 2004, 48). For the first rule, all books recommend using simple or plain English when we formulate questions to make the respondents understand and answer them easily. The second most important rule for the wording found in several books is be brief (Peterson 2000, 50) or use as few words as possible to pose the questions (Dillman et al. 2009, 85); however, Fowler has a slightly different idea about this rule. Although he does not state explicitly how long a question should be or whether it should be long or short, he explains that we should avoid incomplete and poor wording, and poorly defined terms. Then, he presents an example from a short question (which according to him is poor and incomplete, such as "Did you eat breakfast yesterday?") to become a long and clearly defined question ("For our purpose, let us consider breakfast to be a meal, eaten before 10:00 in the morning, that includes some protein such as eggs, meat, or milk, some grain such as toast or cereal, and some fruit or vegetable. Using that definition, did you have breakfast yesterday?") (2002, 76-84). Hence, Fowler does not suggest the question should be brief because what is important for him is the questions should be clearly defined and complete. I think this is quite the challenge because I believe the questions ought to be brief but complete and clearly defined to obtain more reliable answers.

The third rule is be relevant (Peterson 2000, 52) or make sure the question applies to the respondent (Dillman et al. 2009, 79). For this rule, I believe different questions should be asked to different types of 
respondents based on, for instance, their living area since they might experience different things. ${ }^{3}$ The fourth rule is ask one question at a time (Dillman et al. 2009, 81) or avoid multiple questions (Fowler 2002, 84-85). For instance, for the sample of the survey in the appendix, I should not ask "Did you pass or fail the UKP?" because it will bring confusion to the answer since we will not know which component the respondents are referring to when they marked "yes" or "no" (Dillman et al. 2009, 81). The fifth rule is be specific (Peterson, 2000,56 ) or use specific and concrete words to specify the concepts clearly (Dillman et al. 2009, 84). Fink also states that we should not ask very general questions, especially for retrospective ones, so that the respondents could also give specific answers $(2006,33)$. The last is be objective or should not be biased (Peterson 2000, 57-58). We should not ask the questions we already know the answer for, and we must not lead the respondents to choose the desired answers (lbid.).

\section{Conclusion}

All the considerations and rules to develop a questionnaire gathered from several books above do not necessarily guarantee us to produce good questions to obtain the expected results. We should really think hard to formulate the questions to dig out information from the right respondents for our research. However, at least those considerations and rules give us a good start to design our questionnaire. With a proper questionnaire and the right questions to ask, we will be able to gather adequately significant data to build our research paper.

\section{Bibliography}

Baddeley, Alan. 2004. The Limitations of Human Memory: Implications for the Design of Restrospective Surveys. In Martin Bulmer (Ed.), Questionnaires: Volume IV, 29-45. Sage Publications, Inc.

Blau, P.M. 1964. Exchange and Power in Social Life. New York: Wiley.

Dillman, Don A., Smyth, Jolene D., and Christian, Leah Melani. 2009. Internet, Mail, and Mixed-Mode Surveys: The Tailored Design Method. Hoboken, New Jersey: John Wiley \& Sons, Inc.

Fink, Arlene. 2006. How to Conduct Surveys: A Step-by-Step-Guide. Sage Publication, Inc.

Fowler, Floyd J. 2002. Survey Research Methods. Sage Publication, Inc.

3 For my research, I should give two types of questionnaires: (1) for people living in Jakarta and its surrounding areas and having tried UKP (Indonesian Translation Qualification Exams), (2) for people living outside Jakarta to obtain data about legal translation activity there without UKP, since UKP is only held in Jakarta. 
Groves, R.M., Cialdini, R., \& Couper, M.P. 1992. Understanding the decision to participate in a survey. Public Opinion Quarterly, 56, 475-495.

Gillham, Bill. 2000. Developing a Questionnaire. Padstow, Cornwall: T.J. International.

Homans, G. 1961. Social Behavior: Its Elementary Forms. New York: Harcourt, Brace \& World.

Menner, Peter. 2004. Retrospective Data in Survey Research. In Martin Bulmer (Ed.), Questionnaires: Volume IV, 46-60. Sage Publications, Inc.

Peterson, Robert A. 2000. Constructing Effective Questionnaires. Sage Publications, Inc.

\section{Appendix 1}

The Sample of Introductory Section or The Cover Letter of The Questionnaire 
Dear Mr/Ms.

I am conducting a survey to obtain information on legal translation history in Indonesia related to UKP (Indonesian Translator Qualification Exams).

I would greatly appreciate your completing the enclosed questionnaire, and you could have around 2 weeks to answer the questions. It will be plenty of time for you to think about the answers. Your answers will be a great help for my research.

Please send the complete questionnaire through this email; answer every question as well as you can. Because only a relatively small number of people are being surveyed, your response is very important to me.

Your answers will, of course, be strictly confidential, and this questionnaire is anonymous.

Thank you in advance for your time and effort.

Cordially,

Haru Deliana Dewi

Researcher

\section{Appendix 2}

\section{Questionnaire Questions}

The Questionnaire for People Living in Jakarta and its Suburbs 
1. When did you take UKP for the first time? Please mention the year.

2. How did you do the test?
a. Manually.
b. Computerized.
c. Others:

3. Did you pass?

4. If you failed, could you explain why?
a. I was not ready.
b. The time was not enough.
c. The test was very difficult.
d. Others:

5. How many times have you taken UKP?
a. Only once.
b. Twice.
c. Three times.
d. More than 3 times.

6. If you have taken more than once, please explain why.
a. I failed and want to pass the test.
b. I have passed one kind of test, and want to pass another one (there are 2 kinds of tests: English-Indonesian test and Indonesian-English test).
c. Others:

7. Have you noticed any differences from your first UKP experience to the next one?
a. The place:
b. The procedure:
c. The test:
d. The result announcement:

8. Do you prefer the manual or computerized UKP? Please explain why.
a. Advantages of manual UKP:
b. Disadvantages of manual UKP:
c. Advantage of computerized UKP:
d. Disadvantages of computerized UKP:

9. In your own opinion, what is the significance of UKP toward the legal translation practice in Indonesia?
a. Very significant.
b. Significant.
c. Not significant.
d. Not very significant. 
10. Based on your response in number 9 , please provide an explanation of your answer!

Thank you very much for your participation.

The Questionnaire for People Living outside Jakarta and its Suburbs

1. Have you ever heard about UKP?

a. How have you heard it?

b. From the institution where I work. 
c. From an acquaintance in Jakarta.

d. Others:

2. What do you think of it?

a. It is a good test for translators.

b. I don't know.

c. I don't care.

d. It is a bad test for translators.

e. Why is it only held in Jakarta and only for people living there?

f. Others:

3. Has there been a similar test for translators to get certification, especially in legal translation, in your area? If yes, please name the test.

4. If your official documents should be translated by a sworn translator, what would you do?

a. just find any translator (not a sworn translator) in your area.

b. find a sworn translator from Jakarta.

c. translate it myself.

d. Others:

5. And what did you do to have those documents translated based on your experience?

6. Do you think UKP should also be held outside Jakarta? Please explain your answer!

7. What have you heard so far about the protest and complaints for UKP only being held in the Capital City?

Thank you very much for your participation. 